\title{
EDITORS' CORNER
}

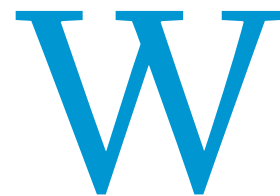
elcome to the 51st volume of $P S$ : Political Science \& Politics! We are excited to announce that we have been reappointed to a second term as coeditors of the journal. We would like to thank the review committee, the publications committee of the APSA Council, and the council for endorsing our proposal to serve a second term. We also want to thank our editorial board which has been expanded and reinvigorated. Our board meeting at the APSA Annual Meeting was the best attended in our term as editors, and we had an active and lively discussion over our editorial policies and content categories.

Our reappointment included a mandate to continue to work on a number of initiatives intended to diversify our content and author pool and to clarify some of our editorial policies. We have begun these discussions with our editorial board and the publications committee and will begin to push out these changes to our readership.

We have been asked to assure that our Symposia and Spotlights, some of the most popular content areas in $P S$, are accessible to all scholars. In response, we are considering adding a requirement for an "open call" policy for proposed symposia. While the details of this change still need to be worked out, this change would mean Symposium and Spotlight proposals would no longer consist of a pre-determined set of papers, but would identify and justify an area of coverage and include a system for managing an open call. Alternatively, we may allow for proposals with an established list of papers, but require a statement of outreach efforts to younger scholars and scholars from underrepresented groups.

Another major change we have been asked to implement is to move to "First View." Scholars may not realize the version of an article published on First View must be the version of record, meaning there can be no changes between the First View version and the version that appears in print. The unique production features of $P S$ (e.g., our use of "pull quotes" and other special formatting) makes First View more challenging to implement, but we have worked to adapt our production workflow. We are rolling out First View with this issue.

This January issue has several outstanding Symposia and Spotlights addressing contemporary politics and important issues to the profession.

William D. Hicks and Carol Weissert's Spotlight, "Home Rule Be Damned: Exploring Policy Conflicts between the Statehouse and City Hall" addresses the growing tensions between state and local governments across the country and the significant policy and political implications of these conflicts.

Charles Crabtree and Christian Davenport's Spotlight, "Contentious Politics in the Trump Era" examines recent events in American politics through the lens of the contentious politics literature, providing new insights and directions for future research.

Frances Lee's symposium on the APSA congressional fellows provides reflections on the APSA Congressional Fellowship
Program and highlights the diversity of work and research by the most recent class of fellows.

Mathew Manweller and David Lublin organized a set of articles by political scientists who have run for and been elected to political office. In many ways, it is a followup to our previous symposium by Carl Klarner, "Beyond the Ivory Tower: Political Science Careers Outside Academia" (49:3). It's fascinating to read what lessons political scientists took to their experiences in elective office, and in how many ways politics is very different from political science.

Finally, we want to thank Barbara Walthall for her many years of service, previously as managing editor of $P S$, and subsequently as Director of Publications for the association. Barbara tutored us, hectored us, and ultimately became our partner in editing $P S$ for our first year, and was instrumental in training Celina Szymanski as our current managing editor. Her presence in our professional lives is ending, but our personal connections remain.

Her successor, Jon Gurstelle, joins APSA from John Wiley \& Sons. We have invited Jon to write a brief introductory essay about publication, citations, and the best way to title your articles so that they attract a wider readership (short version: titles do matter!) which will appear in our April issue. Welcome to Jon!

-Phillip Ardoin
Appalachian State University
-Paul Gronke
Reed College




\section{Achieving Diversity and Inclusion in Political Science}

\section{Diversity and Inclusion Programs}

The American Political Science Association has several major programs aimed at enhancing diversity within the discipline and identifying and aiding students and faculty from underrepresented backgrounds in the political science field. These programs include:

Ralph Bunche Summer Institute (RBSI) (Undergraduate Juniors)

The RBSI Program is an annual five-week program designed to introduce undergraduate students from under represented racial/ethnic groups, or students interested in broadening participation in political science and pursuing scholarship on issues affecting under-represented groups, to the world of graduate study and to encourage application to PhD programs. Application deadline: January of each year. For more information, visit www.apsanet.org/rbsi.

APSA Minority Fellows Program (MFP) (Undergraduate Seniors or MA and PhD students) (Fall Cycle for seniors and MA Students, Spring Cycle for PhD students) MFP is a fellowship competition for those applying to graduate school, designed to increase the number of individuals from under-represented backgrounds with PhD's in political science. Application deadline: October and March of each year. For more information, visit www.apsanet.org/mfp.

Minority Student Recruitment Program (MSRP) (Undergraduates and Departmental members) The MSRP was created to identify undergraduate students from under-represented backgrounds who are interested in, or show potential for, graduate study and, ultimately, to help further diversify the political science profession. For more information, visit www.apsanet.org/msrp.

\section{APSA Mentoring Program}

The Mentoring Program connects undergraduate, graduate students, and junior faculty to experienced and senior members of the profession for professional development mentoring. APSA membership is required for mentors. To request a mentor or be a mentor, visit www.apsanet.org/mentor.

\section{APSA Status Committees}

APSA Status Committees develop and promote agendas and activities concerning the professional development and current status of under-represented communities within the political science discipline. For a listing of all APSA status committees, visit www.apsanet.org/status-committees.

For more information on all Diversity and Inclusion Programs, visit us online at www.apsanet.org/ diversityprograms. Please contact Kimberly Mealy, PhD, Senior Director of Diversity and Inclusion Programs with any questions: kmealy@apsanet.org.

To contribute to an APSA Fund, such as the Ralph Bunche Endowment Fund or the Hanes Walton Jr. Fund, visit us at www.apsanet.org/donate. 